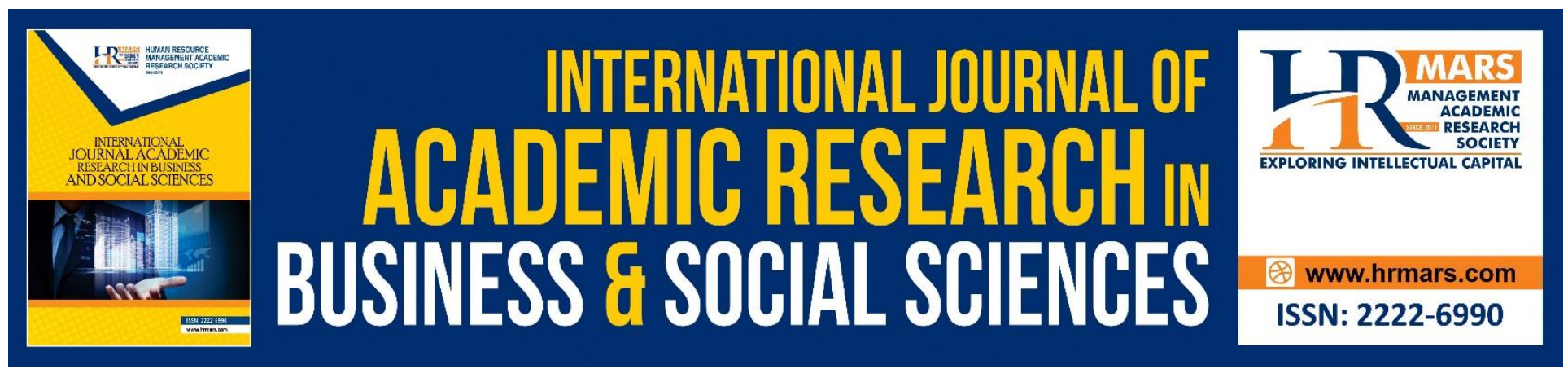

\title{
Distance Education: Historical Overview and Current Practices in Malaysian Higher Education
}

\author{
Nur Aira Abdrahim
}

To Link this Article: http://dx.doi.org/10.6007/IJARBSS/v8-i12/4989

DOI: 10.6007/IJARBSS/v8-i12/4989

Received: 03 Nov 2018, Revised: 09 Dec 2018, Accepted: 13 Dec 2018

Published Online: 16 Dec 2018

In-Text Citation: (Abdrahim, 2018)

To Cite this Article: Abdrahim, N. A. (2018). Distance Education: Historical Overview and Current Practices in Malaysian Higher Education. International Journal of Academic Research in Business and Social Sciences, 8(12), 33-45.

Copyright: (C) 2018 The Author(s)

Published by Human Resource Management Academic Research Society (www.hrmars.com)

This article is published under the Creative Commons Attribution (CC BY 4.0) license. Anyone may reproduce, distribute, translate and create derivative works of this article (for both commercial and non-commercial purposes), subject to full attribution to the original publication and authors. The full terms of this license may be seen

at: $\underline{\text { http://creativecommons.org/licences/by/4.0/legalcode }}$

Vol. 8, No. 12, 2018, Pg. 33 - 45

Full Terms \& Conditions of access and use can be found at http://hrmars.com/index.php/pages/detail/publication-ethics 


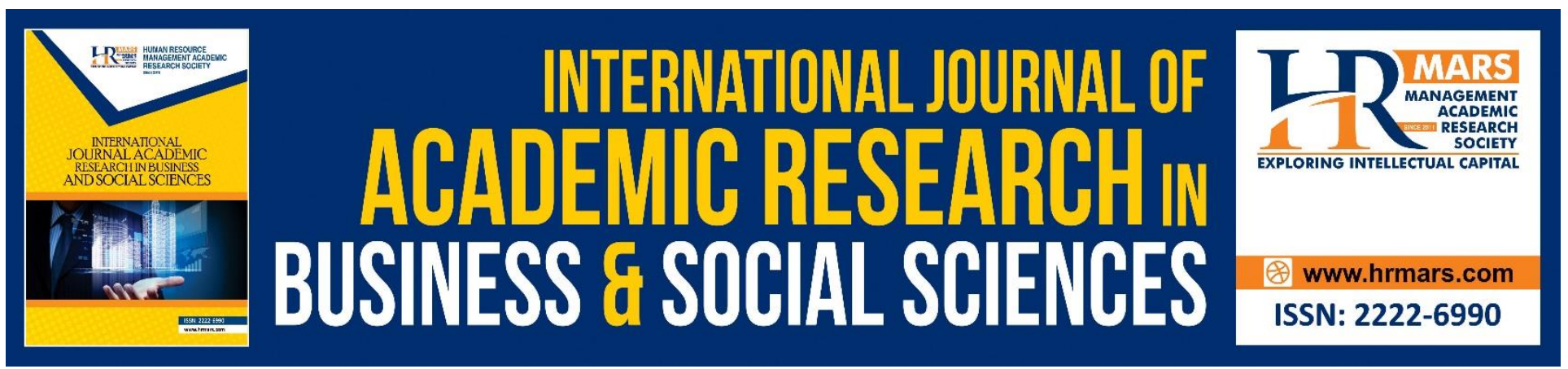

\title{
Distance Education: Historical Overview and Current Practices in Malaysian Higher Education
}

\author{
Nur Aira Abdrahim \\ Department of Continuing Education \& Professional Development, Faculty of Educational Studies, \\ Universiti Putra Malaysia
}

\begin{abstract}
Distance education is a dynamic and complex area of inquiry. Ever since its early conception, distance education has undergone various theoretical development to reflect the ongoing changes and practices in the field. In particular, the field has vastly been influenced by the advent of various technologies in communication and information delivery systems since the start of 21st century. The first part of this article addressed the key historical developments of distance education in higher education. Next, various definitions of distance education and its related terms were presented. This article also discusses the overview of current practices of distance education in Malaysian higher education.
\end{abstract}

Keywords: Distance education, Distance learning, Online learning, Higher education, Education history

\section{Introduction}

It was recognized that the formal starting point of distance education in higher education begins with the introduction of correspondence education (Black, 2007; Garrison, 1989; Harting \& Erthal, 2005; Pittman, 2007). Print-based correspondence education is considered the first generation and the oldest form of distance education (Archer \& Garrison, 2010). Traditionally, the print-based materials are mailed to the learners, and any coursework completed by the students will be returned via the same way for grading (Schlosser, 2006). The cycle will be repeated until the course or program requirements are completed. Correspondence education practice is considered among the first few efforts established to promote equal access opportunities for education. Back during the time when education is considered a part of elitism, this alternative form of education was designed to provide access to the underprivileged and to those who cannot afford to be in full time residence at an educational institution (Gunawardena \& Mclsaac, 2004).

The first formally established correspondence program in higher education was offered at the University of Chicago during the late 1800s (Moore \& Kearsley, 1996). However, prior to that, it was the Chautauqua movement that helped popularize the concept of correspondence study to the 
general public (Harting \& Erthal, 2005). The concept of home-study courses was introduced through the Chautauqua summer institute, where the institute utilized materials from the Chautauqua publishing house to supplement the courses. Following to the Chautauqua movement's success, universities begin to adopt the correspondence-for-credit arrangement into their practice.

Harting and Erthal (2005) and Moore and Kearsley (1996) further provide the historical background on the development of distance education in higher education. Influenced by the Chautauqua movement, universities such as Oxford and Cambridge begin to offer correspondence courses via the university extension services. Following to Illinois Wesleyan University's successful home study program, the founding of 'Correspondence University' in Ithaca and the International Correspondence School in Pennsylvania, a university-based correspondence program found its first home at the University of Chicago. William Rainey Harper, who is once a faculty member at Chautauqua Institute, became the President and established an extension division to deliver the university courses by mail. For this contribution, Harper is known as the father of modern correspondence education. The enactment of the Co-operative Agricultural Extension Act (SmithLever Act) in 1914 further strengthens the university extension and correspondence work in the US.

Another influential scholar of distance and correspondence education is Professor Charles Wedemeyer. He directed the Articulated Instructional Media (AIM) Project and tested the viability of the idea that teaching-learning transactions can function in distance by delivering the instructions through various communication media. This effort is considered the beginning of the idea on the total system of distance education (Moore \& Kearsley, 1996). Wedemeyer's (1981) idea seeded the interest of the British government on its exciting possibilities to shape a revolutionary new educational institution in the UK. This eventually leads to the birth of the British Open University in 1969 as the world's first degree-granting institution to offer programs exclusively in distance. Following to the success of the Open University in Britain, more and more higher education institutions begin to experiment ways to incorporate distance education component into their teaching practices (Harting \& Erthal, 2005).

\section{Key Development of Distance Education in Higher Education}

The evolution of distance education field is vastly influenced by the development of instructional delivery technologies (Moore \& Kearsley, 1996). The introduction of radio and television has allowed educational materials to be broadcasted more widely to the public beyond traditional print materials. After the establishment of distance education as a component of higher education, universities started to actively seek new technologies to help enhance their instructional delivery. Few examples include experiments using the satellite television and teleconferencing network. Subsequently, the introduction of audio conferencing and videoconferencing technologies have paved the way for synchronous distance education to take place. Archer and Garrison (2010) refer to this form of communication as the second generation of distance education. It allows students and instructor to participate in classes simultaneously from different locations (hence, the term synchronous). However, the operating cost to run these technologies was initially very expensive. It was only after the introduction of computer and Internet that these technologies became a feasible instructional delivery option in distance education. 
According to Harting and Erthal (2005), the use of computers as a learning tool went through a resistance period in the late 1970 s and early 1980 s. Computers only started to become a primary tool for distance education after the introduction of high-powers personal computers, broadband communications (including the Internet), and digital video during the 1990s (Harting \& Erthal, 2005). Transition to Generation 3 of fast asynchronous distance education began with the introduction of the World Wide Web (WWW). It involves "electronic transmission of learners' and facilitators' contributions to a learning event into a central server, where materials are stored in a systematic way so that they can be accessed easily by other participants at any time" (Archer \& Garrison, 2010, p. 322). As noted by Archer and Garrison, with the advent of Internet access and development of the World Wide Web, the popularity of web-based education increased exponentially beyond the traditional distance education community. The larger education community in general, including higher education institutions, begins to adopt online practices by initiating electronic online access to learning resources and delivering at least some components of their courses online. New terms, such as e-learning, flexible learning and distributed learning, emerged to address the new development in the distance education field (Archer \& Garrison, 2010; Rudestam \& SchoenholtzRead, 2010). At present, the integration of computer and the Internet technologies is considered the hallmark of contemporary distance education.

Looking back at the historical development of this field, it was noted that the practice of distance education has brought changes into the traditional structure of higher education. Hanna (2003) described the changing organizational contexts in higher education based on Schlecty's (1997) three basic forms of organizational change:

1. Procedural change, which has to do with altering how organizational tasks are accomplished

2. Technological change, which consists of changing the means by which the job is done

3. Structural and cultural (systemic) change, which consists of changing the nature of the work itself and reorienting its purpose (as cited in Hanna, 2003, p. 67).

Hanna asserts that when distance education was first adopted as part of the universities' practice, changes mostly occur from a procedural and technological aspects. These types of changes include practices such as universities developing new units for delivering correspondence courses or changing the instruction delivery modes without altering the content (procedural), and replacing the use of older technologies, such prints, radio and TV, to a more recent technology, such as satellite television and teleconferencing network (technological). The fundamental shift in structural and cultural structure begin to occur following to a vast Internet development that has altered the way communication works. The Internet not only affects the teaching and learning practices in higher education, but also the ways universities administrated their operations. As a result of this systemic shift, the universities are expected to furnish their environments with Internet access and networking system. The readily available facilities have since fueled more efforts to integrate online component into teaching and learning. As online teaching became a common practice in higher education, the distinction between on-campus learning and distance learning is gradually blurring.

As a worldwide phenomenon, the development of distance education field has simulated a lot of intellectual discussion from various scholars. As the field evolves and extends to areas outside of the traditional distance education community, the definitions and understandings of distance 
INTERNATIONAL JOURNAL OF ACADEMIC RESEARCH IN BUSINESS AND SOCIAL SCIENCES Vol. 8, No. 12, Dec, 2018, E-ISSN: 2222-6990 @ 2018 HRMARS

education have become more complex. The language and terms used within the field have also shifted accordingly. The following section discussed the various definitions, terms, and understandings of distance education in higher education context.

\section{Distance Education: Related Terms, Definitions, \& Understandings}

Distance education has been associated with a number of existing terms, although not all are considered synonymous to one another. Several terminologies that were introduced by Keegan (1996) include correspondence education and home study. As previously discussed, correspondence education reflects the earliest form of distance education, while the term home study is mainly used in technical and vocationally oriented institutions. The term 'distance learning' is also synonymously used in reference to distance education, although Moore and Kearsley (1996) argued that the term 'distance education' is more reflective to denote a type of instruction that is deliberate and planned, as compared to distance learning.

There is a plethora of distance education definitions in the literature. Moore (2007) asserts that the term 'distance education' is originated from a German word fernstudim (means "distance study") to describe how certain industrial principles could be applied to the craft of teaching. According to Garrison (1989), the definitions of distance education have been offered from different focus and approaches. Early theorists of distance education, such as Holmberg (1981) have proposed a definition that is grounded in his theory of interaction and communication, while Wedemeyer (1981) and Moore (1973) anchored their definitions of distance education based on the theory of independent learning. Peters (1988) also offered an alternative scientific perspective and viewed distance education as an industrialized form of teaching and learning.

Meanwhile, Keegan (1980) has sought to contribute to the definition of distance education by identifying essential elements in distance education. Based on the synthesis of existing definitions that he studied, Keegan $(1980,1986)$ present his five key elements of distance education to constitute the following:

1. The quasi-permanent separation of teacher and learner throughout the length of the learning process (this distinguishes it from conventional, face-to-face education);

2. The influence of an educational organization in the planning and preparation for learning materials and in the provision of student support services (this distinguishes it from private study and teach-yourself programs).

3. The use of technical media - print, audio, video, or computer - to unite teacher and learner and carry the content of the course

4. The provision of two-way communication so that the student may benefit from or even initiate a dialogue (this distinguishes it from other uses of technology in education)

5. The quasi-permanent absence of the learning group throughout the length of the learning process so that people are usually taught as individuals and not in groups, with the possibility of occasional meetings for both didactic and socialization purposes.

(Keegan, 1986, p. 35)

However, Garrison and Shale (1987) view Keegan's defining elements as being too narrow and problematic. They especially questioned the validity of the fifth defining element, because this element excludes group learning whereas the use of new technologies such as audio and 
videoconferencing do take place in a group. Garrison and Shale conclude that Keegan's definition as being heavily rooted in independent print-based form of distance study and is not responsive to the current changes in instructional delivery technology. Instead, Garrison and Shale (1987) offered their own criteria for characterizing the distance education process, where:

1. Distance education implies that the majority of educational communication between (among) teacher and student(s) occurs noncontiguously.

2. Distance education must involve two-way communication between (among) teacher and student(s) for the purpose for facilitating and supporting the educational process.

3. Distance education uses technology to mediate the necessary two-way communication

(Garrison \& Shale, 1987, p. 11)

As synchronous distance education became more prominent, the definitions of distance education gradually evolved to include discussion on telecommunications and other technological support in learning (Barker, Frisbie, \& Patrick, 1993). Learning activities are synchronous when they allow learners to have a level of interactive at the same moment of time (Mason \& Rennie, 2006). Under this new emerging context, the term distance education is intended to refer to "the simultaneous telecommunicated delivery of instruction from a host site of classroom to distance sites, coupled with live audio and/or video interaction between teacher and student" (p. 40) instead of correspondence study. In addition, telecommunications technology has shifted the educational dynamic from being individual-centered to a more group-based learning (Dabbagh \& Bannan-Ritland, 2005). However, two characteristics remain central in the discussion of distance education, referring to the elements of student-teacher separation and the role of media in mediating the communication, with added discussion on the use of electronic media. For example, Moore and Kearsley (1996) maintain the idea that the students-teachers separation is a fundamental concept that distinguishes distance education from the face-to-face instruction. They also regard the use of both printed and electronic technologies as the prime characteristic of distance education. They proposed the following definition of distance education: "Distance education is planned learning that normally occurs in a different place from teaching and as a result requires special techniques of course design, special instructional techniques, special methods of communication by electronic and other technology, as well as special organizational and administrative arrangements" (p. 2)

Simonson, Smaldino, Albright, and Zvacek (2009) shared a similar view with Moore and Kearsley (1996) in regards to their definition of distance education. They positioned their definition of distance education based on four important components as outlined by the Association for Educational Communications and Technology. The first component described distance education as being institutionally based, which help differentiates the concept of distance education from selfstudy. The second component involves the geographical, time and intellectual separations between the teachers and learners. Interactive telecommunications is the third critical component of distance education, and can be delivered in a form of synchronous or asynchronous communication. Telecommunications is defined as "communicating at a distance" and implies the use of both electronic media such as the Internet, as well as the older telecommunication system such as the postal system. The last component examines the concept of connecting the learners, resources, and instructors to form a learning experience. This component looks at interrelationship between the role 
INTERNATIONAL JOURNAL OF ACADEMIC RESEARCH IN BUSINESS AND SOCIAL SCIENCES Vol. 8, No. 12, Dec, 2018, E-ISSN: 2222-6990 @ 2018 HRMARS

of teacher, interactions with learners, and the availability of resources that enable learning to occur in distance. Simonson et al (2009) see these four components as integral and have to co-exist in order to form a complete definition of distance education.

Related online learning terms, definitions, and understandings. As metaphorically described by Archer and Garrison (2010), technologies continue to affect the development in distance education across three different generations. The third generation reflects the current scenario where learning is largely being supported by instructional content that are being electronically transmitted and systematically stored, and made accessible at all times. This is when the term 'elearning' and 'online learning' were coined, and has since become synonymous with the contemporary understanding of distance education. Online learning goes by other different terminologies, which include Internet learning, distributed learning, networked learning, telelearning, virtual learning, computer-assisted learning, web-based learning, and distance learning (Ally, 2004). Moore, Dickson-Dean, and Galyen (2011) have conducted an analysis to examine three related terminologies related to learning in an online context: distance learning, e-learning, and online learning. The term distance learning has been used analogously with distance education in earlier writings to reflect a learning structure that involves a physical separation of location and time between the instructor and learner. Despite the interchangeable usage by many authors and researchers, some efforts have been made to distinguish the two terms. For instance, Salas, Kosarzycki, Burke, Fiore, and Stone (2002) viewed distance learning as a broader term that encompasses both distance education (a term commonly used in academic) and distance training (a term commonly used in industry). In another perspective, Keegan (1996) viewed distance learning as the halve component of distance education, where together with distance teaching, formed a full process of distance education. With the proliferation of technologies used in educational setting, the term distance learning evolved from its traditional structure to new forms of learning i.e. e-learning and online learning.

Moore, Dickson-Deane, and Galyen (2011) noted that most definitions of e-learning in the literature infer to different technological tools and interactivity element as one of the descriptors. The letter 'e' in e-learning normally stands for "electronic" (Pachler \& Daly, 2011). Mason and Rennie (2006) credited Jay Cross for coining the term e-learning in 1998. According to them, definition of elearning varied based on the different emphasis in the aspect of content, communication, or technology. One of the early definitions of e-learning is provided by the American Society for Training and Development (ASTD), where e-learning is positioned as a wide set of applications and processes which does not only include learning content that is being delivered through the Internet and Webbased platforms, but also delivery via CD-ROM, audio-and-videotape, satellite broadcast and interactive TV (Mason \& Rennie, 2006). Rudestam and Schoenholtz-Read (2010) assert that e-learning is a favored term in the literature to described courses and programs offered over the Internet. In similar view, Rosenberg (20001) anchored his e-learning definition on the usage of Internet, referring to e-learning as "the use of Internet technologies to deliver a broad array of solutions that enhance knowledge and performance, based on three fundamental criteria: 1) it is networked; 2) delivered to end-user via computer using standard Internet technology; and 3) focuses on the broadest view of learning." (as cited by Mason \& Rennie, 2006, p. xiv). 
E-learning is often synonymously used with the term 'online learning' (Pachler \& Daly, 2011). As observed by Moore, Dickson-Deane, and Galyen (2011) in the literature, the term online learning is positioned as being wholly online, where access to learning experiences are fully provided through the use of some technology. Dabbagh and Bannan-Ritland (2005) explicated their understanding of online learning as the newer, improved version of distance learning. They provide the definition of online learning as "an open and distributed learning environment that uses pedagogical tools, enabled by Internet and Web-based technologies, to facilitate learning and knowledge building though meaningful action and interaction" (p. 15). They also emphasized on three key components that are essential to foster meaningful learning and interaction in online learning: (a) pedagogical models or constructs; (b) instructional and learning strategies; and (c) pedagogical tools, or online learning technologies (i.e. Internet). These three components formed an iterative relationship where selection of pedagogical model informed the specification of instructional and learning strategies. The learning strategies then, were enacted in the learning design through the use of learning technologies.

In addition to the above, there are other terms that were similarly associated with online learning. For example, Moore, Dickson-Deane, and Galyen (2011) report that a group of participants in their research have grouped "blended learning' and "e-learning" as the same. Blended learning, or hybrid learning, refers to an amalgamation of face-to-face learning and online learning, and is considered the contemporary trend of incorporating distance technology and the Internet into the educational process (Rudestam \& Schoenholtz-Read, 2010). According to Mason and Rennie (2006), blended learning can be formed in different combinations of technologies, locations, or pedagogical approaches.

Web-based learning, or web-based instruction, is another common term used in online learning context. As the name reflects, this term typically refers to a learning structure where the course content is being delivered on the web via the Internet technology (Mason \& Rennie, 2006). Dabbagh and Bannan-Ritland (2005) distinguish web-based instruction as a type of online learning delivery mode, where it can be integrated from various forms of text-based, hypermedia, multimedia, and collaborative resources for the purposes of teaching and learning. In addition, certain terms are also more favorably used in different countries to refer to their online education structure, such as 'flexible learning' in Australia and 'open learning' in the UK (Dabbagh \& Bannan-Ritland, 2005; Mason \& Rennie, 2006). Most recently, a form of open access participative learning known as massive open online course (MOOC) has also became a part of higher education landscape, with expectations to increase access, widening participation, and saving cost (Boyatt, Joy, Rocks, \& Sinclair, 2014).

As concluded by Moore, Dickson-Deane, and Galyen (2011), it is not surprising to learn the inconsistent meaning and various terms used across the landscape of higher education practices, since all learning environments are not alike. The more important matter is for researchers and authors to be clear and sufficiently describe their selected term within a specific context of their research or practice inquiry. This articulation is critical considering the profusion of terms involved in both distance education, online learning and other various related terms. 
INTERNATIONAL JOURNAL OF ACADEMIC RESEARCH IN BUSINESS AND SOCIAL SCIENCES Vol. 8, No. 12, Dec, 2018, E-ISSN: 2222-6990 @ 2018 HRMARS

\section{Historical Overview and Current Practices of Distance Education in Malaysian Higher Education}

The field of distance education has evolved over the course of almost two centuries. With the invention of the World Wide Web and enormous innovation in telecommunication technologies, distance education in various forms, has since been altering the landscape of higher education in terms of instructional delivery and knowledge information practices.

In Malaysia, literature that focuses on the development of distance education practices in higher education has been sporadic and incoherent. The earliest practice of distance education among public university in Malaysia was led by Universiti Sains Malaysia (USM) under the Malaysian government's directive, which also precluded other public universities to operate such educational programs during that time (Arger, 1990; Dhanarajan; 1986). The program was launched in 1971 on experimental basis; and continued as regular program as part of an established academic practice, starting from 1982 (Dhanarajan; 1986). This DE initiative was housed under the Centre for Educational Studies in USM, with mandates to meet several objectives:

1. To help those adults who had earlier missed the opportunity for obtaining higher education and thus qualify for a degree;

2. To narrow the gap of educational objectives among the various ethnic groups in the country;

3. To take education to economically deprived and geographically isolated areas;

4. To increase the nation's (supply of) high level manpower; and

5. To improve the performance of those already employed by updating their knowledge and skills

(Dhanarajan, 1986, p. 568)

The objectives aligned with the noble spirit that seeded the idea of distance education historically; that is to narrow the gap and widen educational access to those otherwise excluded from such opportunities due to geographical and other exclusions. The instructional materials primarily relied on print materials at the beginning, and slowly diversified into non-print materials as using radio broadcast, video and audiocassettes for improved interactivity. The delivery system also includes three weeks of residential on-campus attendance on annual basis, designed to provide the $D E$ students with access to interpersonal communication and consultation with the key academics on campus who taught the courses. However, as with the global trend, persistency of these DE students and completion rates were very low, reflecting a consistent issue that was (and still is) pervasive for such learning structure worldwide.

In Malaysia, changes in higher education institutions were often propelled by government's policies and initiatives as part of reforming and restructuring the national education agenda. For example, Lee (2004) discussed the impact of globalization that was closely linked to efforts and policies initiated by the government to transform and restructure higher education's role to become an active player in the global economy. Similarly, public universities in Malaysia responded actively 
INTERNATIONAL JOURNAL OF ACADEMIC RESEARCH IN BUSINESS AND SOCIAL SCIENCES Vol. 8, No. 12, Dec, 2018, E-ISSN: 2222-6990 @ 2018 HRMARS

to the government's directive policy for inculcating ICT into HE practices as part of the global trend at the start of 21st century (Bajunid, 2002). The Ministry outlined several strategies and guidelines in support of the policy:

1. The preparation of sufficient and up-to-date tested ICT infrastructure and equipment to all educational institutions

2. The roll-out of ICT curriculum and assessment, and the emphasis of integration of ICT in teaching and learning

3. The upgrading of ICT knowledge and skills in students and teachers

4. Increased usage of ICT in educational management

5. The upgrading of the maintenance and management of ICT equipment in all educational institutions.

(Hassan, 2002)

Alongside with the expectations for universities to become self-autonomous in generating their own revenues, as well as growing with the global trend to provide quality, up-to-date education for increasing their competitiveness in the education market for the larger population, offering distance education courses and programs has now become a common practice among higher education institutions (HEI) in Malaysia to fulfill these purposes. Open University Malaysia (OUM) is currently known as one of the leading accredited institutions for providing online distance learning courses and programs in Malaysia.

At the same time, the expansion of ICT technologies as part of HEl's practices are not only limited and focused on providing programs and courses for distance students alone. Rather, as discussed in the previous section, there were also structural shift in overall DE practices worldwide that impacted the delivery modes in higher education institutions, particularly in providing flexible and blended learning experiences for even regular, on-campus students. In 2014, the Malaysian government spearheaded another nationwide strategy for public universities for integrating MOOCs with on-campus university classes. Open Learning (OpenLearning.com) was appointed as the national's MOOC platform for transforming and delivering these open resources education initiatives. Such initiatives marked Malaysia as the first country in the world to develop a national policy on credit recognition based on MOOC's platform (Fairuz, 2016).

\section{Conclusion}

Distance education was conceived from the noble idea of "democratizing education and encouraging greater rates in participation" (Garrison, 1989, p. 229). This notion fits well into the grounding principles of higher education institutions in educating the larger society. Once the idea became an accepted component of educational practice, the growing nature of distance education has since changed the landscape of higher education. The proliferation of technologies has also impacted the changes in both the structure of distance education and higher education, and led to the introduction of online learning and the birth of many forms of open and flexible learning modes. While many scholars view online learning as the new generation of distance education, the complexity of the online learning field has led to an argument that the field may be more suited to 
be considered as "an emerging field that lies at the junction of distance education, human-computer interaction, instructional technology, and cognitive science" (Larreamendy-Joerns \& Leinhardt, 2006, p. 568). Regardless, the influence of online distance learning has been an inevitable force in education, and will continue to have a role in shaping the core practices of higher education.

\section{Corresponding Author}

Nur Aira Abdrahim,

Senior Lecturer \& Member of PUTRA Future Classroom

Department of Professional Development and Continuing Education, Faculty of Educational Studies, Universiti Putra Malaysia.

Email:nuraira@upm.edu.my

Address: Department of Professional Development and Continuing Education, Faculty of Educational Studies, Universiti Putra Malaysia, 43400 UPM Serdang, Malaysia. 
INTERNATIONAL JOURNAL OF ACADEMIC RESEARCH IN BUSINESS AND SOCIAL SCIENCES

Vol. 8, No. 12, Dec, 2018, E-ISSN: 2222-6990 @ 2018 HRMARS

\section{References}

Ally, M. (2004). Foundations of educational theory for online learning. In T. Anderson (Ed.), The theory and practice of online learning (pp. $15-44$ ). Edmonton, Canada: AU Press, Athabasca University.

Archer, W., \& Garrison, D. R. (2010). Distance education in the age of the internet. In C. E. Kasworm, A. D. Rose \& J. M. Ross-Gordon (Eds.), Handbook of adult and continuing education (2010th ed., pp. 317-326). Thousand Oaks, California: Sage Publication.

Arger, G. (2006). Distancee education in the third world: Critical analysis of the promise and reality. The Journal of Open, Distance, and e-Learning, 5(2), 9 - 18. doi: 10.1080/0268051900050203

Bajunid, I. A. (2001). Explorations of the multiple possibilities and equifinality of development initiatives in the transformation of societies: The case of E-Learning in Malaysia. Paper presented at the ICEE 2001, at Mines Beach Resort, 29 - 30 October.

Barker, B. O., Frisbie, A. G., \& Patrick, K. R. (1993). Broadening the definition of distance education in light of the new telecommunications technologies. In K. Harry, M. John \& D. Keegan (Eds.), Distance education: New perspectives (pp. 39-47). New York, NY: Routledge.

Black, L. M. (2007). A history of scholarship. In M. G. Moore (Ed.), Handbook of distance education (pp. 3-29). Mahwah, NJ: Lawrence Erlbaum Associates.

Boyatt R., Joy M., Rocks C., Sinclair J. (2014) What (Use) is a MOOC?. In: Uden L., Tao YH., Yang HC., Ting IH. (eds) The 2nd International Workshop on Learning Technology for Education in Cloud. Springer Proceedings in Complexity. Springer, Dordrecht.

Dabbagh, N., \& Bannan-Ritland, B. (2005). Online learning : Concepts, strategies, and application. Upper Saddle River, NJ: Pearson Education.

Dhanarajan, G. (1987). Distance Education in Malaysia. Distance Education (Vol.11), Asian Development Bank, Manila.

Fairuz, M. S. (2016, January 18). Malaysia to become first country to develop credit recognition policy for online courses. New Straits Times. Retrieved from https://www.nst.com.my/news/2016/01/122766/malaysia-become-first-country-developcredit-recognition-policy-online-courses

Garrison, D. R. (1989). Distance education. In S. B. Merriam, \& P. M. Cunningham (Eds.), Handbook of adult and continuing education (7th ed., pp. 221-232). San Francisco, CA: Jossey-Bass.

Garrison, D. R., \& Shale, D. (1987). Mapping the boundaries of distance education: Problems in defining the field. American Journal of Distance Education, 1(1), 7-13. doi:10.1080/08923648709526567

Gunawardena, C. N., \& Mclsaac, M. S. (2004). Distance education. In D. H. Jonassen (Ed.), Handbook of research on educational communications and technology (2nd ed., pp. 355-395). Mahwah, NJ: Lawrence Erlbaum.

Hanna, D. E. (2003). Organizational models in higher education, past, and future. In M. G. Moore, \& W. G. Anderson (Eds.), Handbook of distance education (pp. 67-78). Mahwah, NJ: Lawrence Erlbaum Associates.

Harting, K., \& Erthal, M. J. (2005). History of distance learning. Information Technology, Learning, and Performance Journal, 23(1), 35. 
INTERNATIONAL JOURNAL OF ACADEMIC RESEARCH IN BUSINESS AND SOCIAL SCIENCES

Vol. 8, No. 12, Dec, 2018, E-ISSN: 2222-6990 @ 2018 HRMARS

Hassan, S. (2002). Government and eLearning: Harnessing eLearning in the education sector. Paper presented at the National Conference on eLearning 2002, Putra World Trade Center, Kuala Lumpur, 4- 5 July.

Keegan, D. (1986). The foundations of distance education. London: Croom Helm.

Keegan, D. J. (1980). On defining distance education. Distance Education, 1(1), 13-36. doi:10.1080/0158791800010102

Keegan, D. (1996). Foundations of distance education (2nd ed.). London ; New York: Routledge.

Larreamendy-Joerns, J., \& Leinhardt, G. (2006). Going the distance with online education. Review of Educational Research, 76(4), 567-605.

Lee, M. N. N. (2004). Global trends, national policies and institutional responses: Restructuring higher education in Malaysia. Educational Research for Policy \& Practice, 3(1), 31 - 46. doi: 10.1007/s10671-004-6034-y

Mason, R., \& Rennie, F. (2006). Elearning: The key concepts. New York, NY: Routledge.

Moore, J. L., Dickson-Deane, C., \& Galyen, K. (2011). E-learning, online learning, and distance learning environments: Are they the same? The Internet and Higher Education, 14(2), 129-135. doi:10.1016/j.iheduc.2010.10.001

Moore, M. G. (2007). The theory of transactional distance. In M. G. Moore (Ed.), Handbook of distance education (2nd ed., pp. 89-105)

Moore, M. G., \& Kearsley, G. (1996). Distance education: A systems view. Belmont, CA: Wadsworth Publishing Company.

Salas, E., Kosarzycki, M. P., Burke, C. S., Fiore, S. M., \& Stone, D. L. (2002). Emerging themes in distance learning research and practice: Some food for thought. International Journal of Management Reviews, 4(2), 135-153. doi:10.1111/1468-2370.00081

Schlosser, L. A., \& Simonson, M. R. (2006). Distance education: Definition and glossary of terms (2nd ed.). Greenwich, CT: Information Age Publishing.

Simonson, M., Smaldino, S., Albright, M., \& Zvacek, S. (2009). Teaching and learning at a distance: Foundations of distance education (4th ed.). Boston, MA: Pearson Education.

Pachler, N., \& Daly, C. (2011). Key issues in e-learning: Research and practice. New York, NY: Continuum International Publishing Group.

Pittman, V. V. (2007). Correspondence study in the American University: A second historiographic perspective. In M. G. Moore (Ed.), Handbook of distance education (2nd ed., pp. 21-35). Mahwah, NJ: Lawrence Erlbaum Associates.

Rosenberg, M. J. (2001). E-learning : Strategies for delivering knowledge in the digital age. New York: McGraw-Hill.

Rudestam, K. E., \& Schoenholtz-Read, J. (2010). The flourishing of adult online education: An overview. In K. E. Rudestam, \& J. Schoenholtz-Read (Eds.), Handbook of online learning (2nd ed., pp. 1-28). Thousand Oaks, CA: Sage Publications.

Wedemeyer, C. A. (1981). Learning at the back door: Reflections on non-traditional learning in the lifespan. Madison, WI: University of Wisconsin Press. 